\title{
Pomegranate (Punica granatum L.) based Fermented Nutraceutical Product
}

\author{
M. Karan", K.N. Sreenivas, M. Chirag Reddy, G.S. Manjula and \\ H. Mohamad Tayeeb Ulla
}

\author{
Department of Post-Harvest Technology, College of Horticulture, GKVK Post, \\ UHS Campus, Bengaluru, Karnataka, India \\ *Corresponding author
}

\begin{tabular}{|c|c|}
\hline & A B S T R A C T \\
\hline Keywords & \multirow{4}{*}{$\begin{array}{l}\text { Nutraceutical enriched blended beverages were prepared by using different fruit } \\
\text { combination of pomegranate, jamun, kokum and pomegranate rind powder, where } \\
\text { the TSS }\left(14{ }^{\circ} \mathrm{B}\right) \text { was maintained by using raisin syrup. Fermentation was carried } \\
\text { out for } 72 \text { hours using Saccharomyces cerevisiae var. ellipsoideus (MTCC 552). } \\
\text { The fermentate was transferred to pre sterilized bottles and pasteurized and then } \\
\text { left for ageing. The chemical parameters of the blended beverage reveled that } \\
\text { there was an increase in alcohol and titratable acidity content, TSS, pH, ascorbic } \\
\text { acid content were decreased during ageing. Among different blending, } \\
\text { combination Pomegranate aril ( } 50 \%)+ \text { Pomegranate rind powder }(1 \%)+\text { Jamun } \\
\text { pulp }(20 \%)+\text { Kokum }(5 \%) \text { recorded } 8.10{ }^{\circ} \mathrm{B} \text { TSS, } 4.14 \mathrm{pH}, 0.70 \% \text { acidity, } 28.80 \\
\text { mg } 100^{-1} \text { ascorbic acid and } 3.80 \% \text { alcohol. The combination was also rated } \\
\text { superior }(8.3 \text { out of } 9 \text { point hedonic scale rating) by sensory panel. }\end{array}$} \\
\hline $\begin{array}{l}\text { Pomegranate, } \\
\text { Fermented beverage, } \\
\text { TSS, pH, Acidity, } \\
\text { Ascorbic acid and } \\
\text { alcohol. }\end{array}$ & \\
\hline Article Info & \\
\hline $\begin{array}{l}\text { Accepted: } \\
\text { 17 October } 2017 \\
\text { Available Online: } \\
\text { 10 December } 2017\end{array}$ & \\
\hline
\end{tabular}

\section{Introduction}

Nutraceuticals also refer to natural functional/medical foods or bioactive phytochemicals that have health promoting, disease preventing or medicinal properties. These nutraceuticals normally contain the required amount of vitamins, lipids, proteins, minerals etc. depending on their emphases (Zeisel, 1999). Moreover, owing to high astringency, phenolic compounds, tannins and such other factors in some of the fruits, the utilization of these fruits for preparation of various processed products becomes essential, despite of their high nutritional qualities. Therefore, blending of two or more fruit juices and their beverages are thought to be a convenient alternative for its utilization in order to have some value added fruit drinks which are of high quality in respect of sensory and nutritional aspects.

Pomegranate (Punica granatum L.) belongs to the family Punicaceae and native to the Iranian Plateau. The rind of the fruit and the bark of the tree are used as a traditional remedy against diarrhea, dysentery and intestinal parasites. Effective utilization of medicinally important crops like pomegranate becomes an imminent necessity to attain nutritional security of the society. Knowing the medicinal importance of pomegranate, 
blended beverage with jamun, kokum and pomegranate rind powder was prepared through fermentation. Further, to ward off misconception regarding drinking alcohol beverages, developments of products which are having less than 5 per cent alcohol using natural source of sugar, which is similar to many Ayurveda products, helps in better acceptance of the prepared products for enhanced health benefits. So it was proposed to study the preparation of blended beverage from pomegranate using raisin paste as the present technology of manufacturing wine from grapes is available. This wine industry will help to generate rural employment and also will give higher returns to the farmers particularly during the seasonal glut. Keeping in view of the above facts and in order to produce good quality beverages from pomegranate in a hygienic way, the present study entitled "Development of pomegranate (Punica granatum L.) based fermented nutraceutical product" was undertaken.

\section{Materials and Methods}

Fully matured, disease free, pomegranate fruits, jamun, dried Kokum rind were obtained from the market and pomegranate rind powder is prepared in lab by peeling, cutting into small pieces and drying followed by grinding for the experiment. Fruits were washed thoroughly in clean water and pomegranate is peeled and fruits were extracted. Jamun fruit is mashed, dried kokum rind is rehydrated and then used for the experiment. Fruits were blended into different combination viz., $\mathrm{T}_{1}=$ Pomegranate aril $(50 \%)$ + Pomegranate rind powder $(1 \%)+$ Jamun pulp $(20 \%)+$ Kokum $(5 \%) ; \mathrm{T}_{2}=$ Pomegranate aril $(50 \%)+$ Pomegranate rind powder $(1 \%)+$ Jamun pulp $(20 \%)+$ Kokum $(10 \%) ; \mathrm{T}_{3}=$ Pomegranate aril $(50 \%)+$ Pomegranate rind powder $(1 \%)+$ Jamun pulp $(30 \%)+$ Kokum $(5 \%) ; \mathrm{T}_{4}=$ Pomegranate aril $(50 \%)+$ Pomegranate rind powder $(1 \%)+$ Jamun pulp
$(30 \%)+$ Kokum $(10 \%) ; \mathrm{T}_{5}=$ Pomegranate aril $(50 \%)+$ Pomegranate rind powder $(2 \%)+$ Jamun pulp (20\%) + Kokum (5\%); $\mathrm{T}_{6}$ : Pomegranate aril $(50 \%)+$ Pomegranate rind powder $(2 \%)+$ Jamun pulp $(20 \%)+$ Kokum $(10 \%) ; \quad \mathrm{T}_{7}=$ Pomegranate aril $(50 \%)+$ Pomegranate rind powder $(2 \%)+$ Jamun pulp $(30 \%)+$ Kokum $(5 \%) ; \mathrm{T}_{8}$ : Pomegranate aril $(50 \%)+$ Pomegranate rind powder $(2 \%)+$ Jamun pulp (30\%) + Kokum (10\%); $\mathrm{T}_{9}=$ Pomegranate- $14{ }^{\circ} \mathrm{B}$ (Control) (Fig. 1).

The TSS of must was maintained at $14{ }^{\circ} \mathrm{B}$ for all treatments using raisin juice. These treatments were evaluated for their biochemical composition during storage period and sensory qualities after three months of storage.

The experiment was carried out with nine different treatments and five replications, using completely randomized design. Pomegranate blended nutraceutical beverage was analyzed for $\mathrm{pH}$, TSS, acidity, ascorbic acid for three months of storage at regular intervals. Various physico-chemical characteristics of the blended beverage were analyzed as per the standard methods. Total soluble solids (\%) were measured using ATAGO pocket refractometer. The total titratable acidity of pomegranate blended nutraceutical beverage was determined by titration method (Ranganna, 1986). The $\mathrm{pH}$ was measured using I Trans Bench top $\mathrm{pH}$ meter, after standardization with buffers of pH 4 and 9. Ethanol content was determined by spectrophotometric method (Caputi et.al., 1968) using potassium dichromate. The absorbance was taken at $600 \mathrm{~nm}$ in a spectrophotometer The standard curve was prepared using pure ethanol in concentrations ranging from 0 to 8 per cent and the of ethanol in the experimental sample were determined and expressed as per cent. Vitamin-C was determined by 2, 6Dichlorophenol-Indophenol visual titration 
method described by Ranganna (1986). The capacity of a sample to reduce a standard dye solution is directly proportional to the ascorbic acid content.

\section{Results and Discussion}

\section{Total soluble solids ( TSS $^{\circ}$ B)}

Fermented nutraceutical of Pomegranate aril $(50 \%)+$ Pomegranate rind powder $(1 \%)+$ Jamun pulp $(30 \%)+$ Kokum $(5 \%)-\mathrm{T}_{3}$ was found to be significant with higher TSS of $8.10^{\circ} \mathrm{B}$. The lowest TSS $\left(7.06^{\circ} \mathrm{B}\right)$ was observed in treatment $\mathrm{T}_{9}$ - Pomegranate - 14 ${ }^{\circ} \mathrm{B}$ and during storage, the pomegranate blends showed decreased TSS as the storage period advanced in all the treatments, this might be due to conversion of sugars to alcohol by yeasts and also consumption of sugars by wild yeast. Similar results are also obtained in grapes was reported by Patil (1994) where TSS of must decreased to $8{ }^{\circ} \mathrm{B}$ and Taskar (2007) reported that the TSS content decreased sharply from 23.0 to 8.2 ${ }^{\circ}$ Brix during fermentation. Later on, the rate of fermentation was declined but continued at a much slower rate up to 8 days during which a decrease of 12.9 per cent in TSS was noted, whereas, Kulkarni et al., (1980) found that by adding sugar to mango pulp of low TSS could raise sugars to $20^{\circ} \mathrm{B}$. The increased TSS may be attributed to less alcohol content and as storage period increases TSS content decreased it might be due to concentration of the nutrient resulted in higher alcohol yield and thus less TSS (Table 1).

\section{pH}

Decreasing trend of $\mathrm{pH}$ was observed in the pomegranate blends as the storage duration increased. The treatment $\mathrm{T}_{9}$ - Pomegranate $14{ }^{\circ} \mathrm{B}$ (Control) recorded highest $\mathrm{pH}$ (3.76) in the fermented nutraceutical contain pomegranate (100 per cent), the $\mathrm{pH}$ was low which might be due to production of acid by wine yeast during the fermentation process. The results are in concurrence with the findings of Olasupo and Obayori (2003). These results are on par with the results of Bravo and Inigo (1989) that increase in acidity would have resulted in decrease in $\mathrm{pH}$ at lower concentrations of sugar. Adsule et al., (1995) opined that the production of malic, lactic, citric, and tartaric acid resulted in decreasing the $\mathrm{pH}$ (Table 2).

\section{Titratable acidity (\%)}

An increased acidity was observed in all the treatments of the pomegranate blends as the storage duration increased. The highest acidity $(1.03 \%)$ was observed in treatment $\mathrm{T}_{9}$ - Pomegranate - $14{ }^{\circ} \mathrm{B}$ (Control) which might be due to the consumption of sugars in the must by yeasts leading to the accumulation of organic acid which lead to higher acidity of fermented nutraceutical. The lowest acidity (0.70) per cent was observed in Pomegranate aril $(50 \%)+$ Pomegranate rind powder $(1 \%)+$ Jamun pulp $(30 \%)+$ Kokum $(5 \%)-\mathrm{T}_{3}$. The increase in titratable acidity in fermentation might be due to the production of certain organic acids by yeast cells. The results were in similarity with the results were reported by Sapna et al., (2002), where in their study of fermentation by different herbs, more titratable acidity was found in thyme wine $(1.39 \%)$ which was followed by French basil $(1.24 \%)$ and lower in Melissa wine $(0.80 \%)$ after nine weeks of storage of wines. Similar results were reported by Laminkanra (1997) were they found the changes in organic acid composition during fermentation and ageing of Noble muscadine wine and reported that formation of succinic acid appeared to be responsible for the characteristic increase in total acidity during seven months storage. The results are on par with the findings of Olasupo and Obayori (2003) the initial per cent acidity was 0.42 which increased to 0.83 (Table 3 ). 
Fig.1 Flow chart of preparation of pomegranate blended nutraceutical

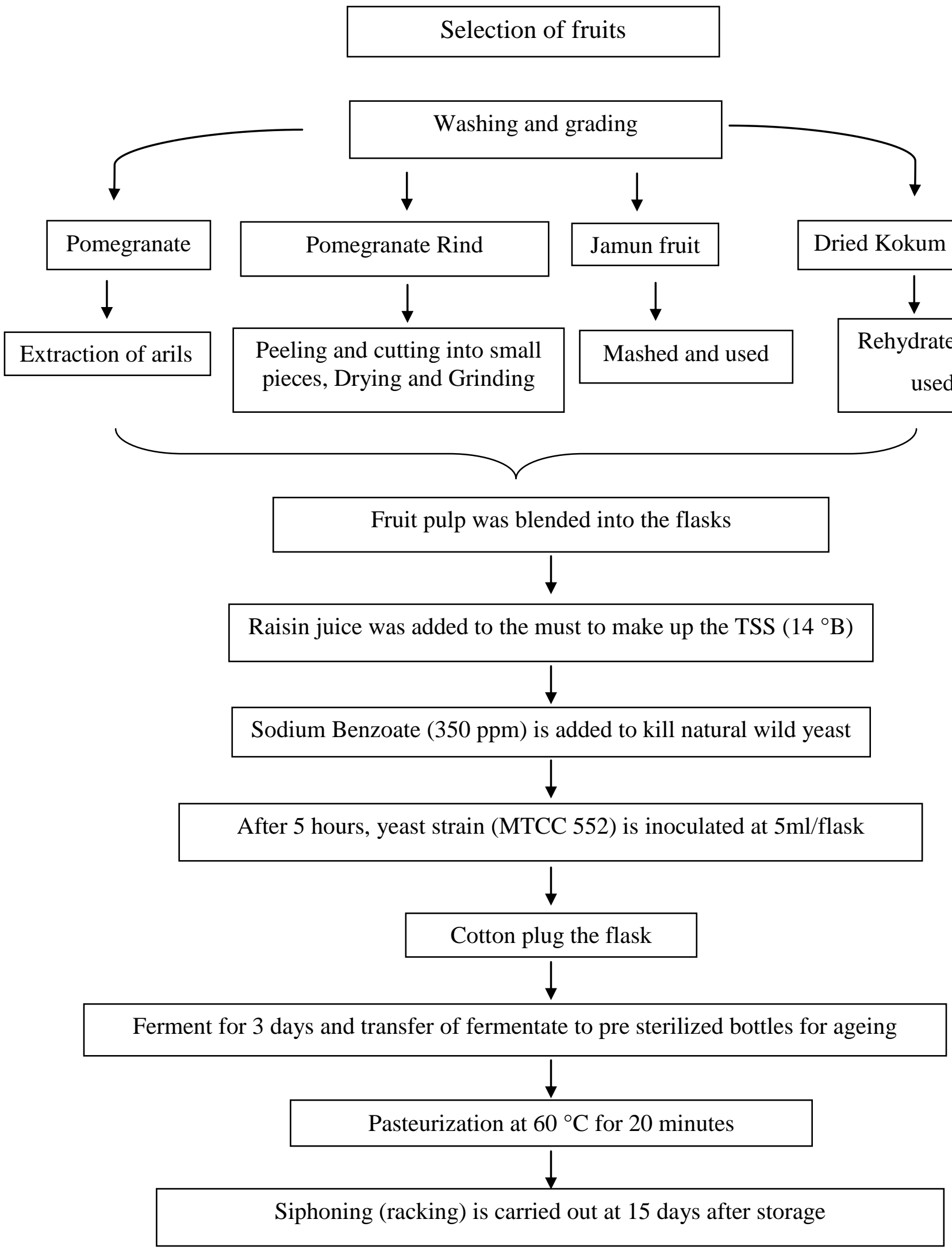




\section{Int.J.Curr.Microbiol.App.Sci (2017) 6(12): 2054-2063}

Fig.2 Sensory evaluation of nutraceutical enriched blended beverages

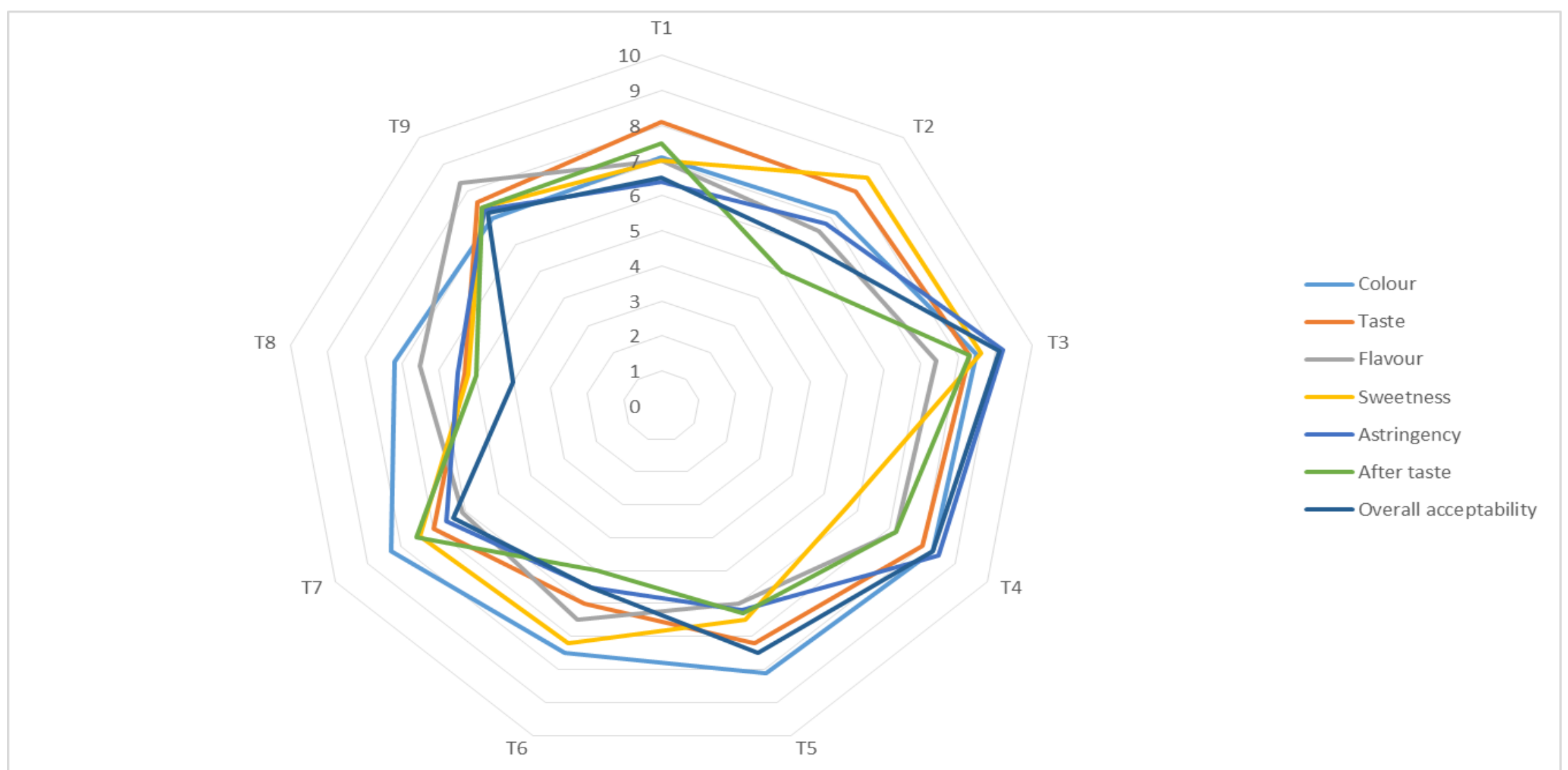

$\mathbf{T}_{1}$ : Pomegranate aril (50\%) + Pomegranate rind powder (1\%) + Jamun pulp $(20 \%)+$ Kokum $(5 \%)$

$\mathbf{T}_{6}$ : Pomegranate aril (50\%) + Pomegranate rind powder (2\%) + Jamun pulp $(20 \%)+\operatorname{Kokum}(10 \%)$

$\mathbf{T}_{2}$ : Pomegranate aril $(50 \%)+$ Pomegranate rind powder (1\%) + Jamun pulp $(20 \%)+$ Kokum $(10 \%)$

$\mathbf{T}_{7}$ : Pomegranate aril (50\%) + Pomegranate rind powder (2\%) + Jamun pulp $(30 \%)+$ Kokum $(5 \%)$

$\mathbf{T}_{3}$ : Pomegranate aril $(50 \%)+$ Pomegranate rind powder $(1 \%)+$ Jamun pulp $(30 \%)+\operatorname{Kokum}(5 \%)$

$\mathbf{T}_{8}$ : Pomegranate aril (50\%) + Pomegranate rind powder (2\%) + Jamun pulp

$\mathbf{T}_{4}$ : Pomegranate aril $(50 \%)+$ Pomegranate rind powder $(1 \%)+$ Jamun pulp $(30 \%)+$ Kokum $(10 \%)$

$(30 \%)+$ Kokum $(10 \%)$

$\mathbf{T}_{5}$ : Pomegranate aril $(50 \%)+$ Pomegranate rind powder $(2 \%)+$ Jamun pulp $(20 \%)+\operatorname{Kokum}(5 \%)$ 
Table.1 Effect of different treatments on TSS $\left({ }^{\circ} \mathrm{B}\right)$ content of nutraceutical enriched blended beverages during storage

\begin{tabular}{|c|c|c|c|c|c|c|c|}
\hline Treatments & 0 Days & 15 Days & 30 Days & 45 Days & 60 Days & 75 Days & 90 Days \\
\hline $\mathrm{T}_{1}$ & 8.44 & 8.30 & 8.16 & 8.08 & 7.98 & 7.90 & 7.82 \\
\hline $\mathrm{T}_{2}$ & 8.32 & 8.16 & 8.08 & 8.00 & 7.92 & 7.86 & 7.78 \\
\hline $\mathrm{T}_{3}$ & 8.88 & 8.74 & 8.60 & 8.48 & 8.36 & 8.22 & 8.10 \\
\hline $\mathrm{T}_{4}$ & 8.66 & 8.50 & 8.36 & 8.24 & 8.12 & 7.98 & 7.90 \\
\hline $\mathrm{T}_{5}$ & 8.02 & 7.90 & 7.82 & 7.70 & 7.64 & 7.56 & 7.48 \\
\hline $\mathrm{T}_{6}$ & 7.92 & 7.78 & 7.62 & 7.52 & 7.40 & 7.32 & 7.26 \\
\hline $\mathrm{T}_{7}$ & 8.24 & 8.10 & 8.00 & 7.92 & 7.84 & 7.74 & 7.66 \\
\hline $\mathrm{T}_{8}$ & 8.16 & 8.04 & 8.12 & 7.80 & 7.72 & 7.66 & 7.60 \\
\hline $\mathrm{T}_{9}$ & 7.76 & 7.62 & 7.50 & 7.36 & 7.22 & 7.14 & 7.06 \\
\hline $\mathrm{CD}$ & 0.238 & 0.248 & 0.297 & 0.213 & 0.197 & 0.219 & 0.202 \\
\hline $\mathrm{SEm} \pm$ & 0.062 & 0.064 & 0.077 & 0.055 & 0.051 & 0.057 & 0.052 \\
\hline F test & $* *$ & $* *$ & $* *$ & $* *$ & $* *$ & $* *$ & $* *$ \\
\hline
\end{tabular}

** Significant at $1 \%$ level

NS - Non Significant

\section{Treatment details}

$\mathrm{T}_{1}$ : Pomegranate aril (50\%) + Pomegranate rind powder (1\%) + Jamun pulp (20\%) + Kokum (5\%)

$\mathrm{T}_{2}$ : Pomegranate aril $(50 \%)+$ Pomegranate rind powder $(1 \%)+$ Jamun pulp $(20 \%)+$ Kokum (10\%)

$\mathrm{T}_{3}$ : Pomegranate aril $(50 \%)+$ Pomegranate rind powder $(1 \%)+$ Jamun pulp (30\%) + Kokum (5\%)

$\mathrm{T}_{4}$ : Pomegranate aril $(50 \%)+$ Pomegranate rind powder $(1 \%)+$ Jamun pulp $(30 \%)+$ Kokum $(10 \%)$

$\mathrm{T}_{5}$ : Pomegranate aril $(50 \%)+$ Pomegranate rind powder $(2 \%)+$ Jamun pulp (20\%) + Kokum $(5 \%)$

$\mathrm{T}_{6}$ : Pomegranate aril $(50 \%)+$ Pomegranate rind powder $(2 \%)+$ Jamun pulp $(20 \%)+$ Kokum $(10 \%)$

$\mathrm{T}_{7}$ : Pomegranate aril $(50 \%)+$ Pomegranate rind powder $(2 \%)+$ Jamun pulp $(30 \%)+$ Kokum $(5 \%)$

$\mathrm{T}_{8}$ : Pomegranate aril $(50 \%)+$ Pomegranate rind powder $(2 \%)+$ Jamun pulp $(30 \%)+$ Kokum (10\%)

$\mathrm{T}_{9}$ : Pomegranate- $14{ }^{\circ} \mathrm{B}$ (Control)

Table. 2 Effect of different treatments on $\mathrm{pH}$ of nutraceutical enriched blended beverages during storage

\begin{tabular}{|c|c|c|c|c|c|c|c|}
\hline Treatments & 0 Days & 15 Days & 30 Days & 45 Days & 60 Days & 75 Days & 90 Days \\
\hline $\mathrm{T}_{1}$ & 4.51 & 4.44 & 4.34 & 4.26 & 4.21 & 4.15 & 4.09 \\
\hline $\mathrm{T}_{2}$ & 4.47 & 4.40 & 4.30 & 4.23 & 4.17 & 4.10 & 4.03 \\
\hline $\mathrm{T}_{3}$ & 4.55 & 4.47 & 4.39 & 4.32 & 4.26 & 4.22 & 4.14 \\
\hline $\mathrm{T}_{4}$ & 4.53 & 4.46 & 4.36 & 4.29 & 4.24 & 4.19 & 4.11 \\
\hline $\mathrm{T}_{5}$ & 4.25 & 4.17 & 4.10 & 4.04 & 3.98 & 3.93 & 3.87 \\
\hline $\mathrm{T}_{6}$ & 4.23 & 4.15 & 4.08 & 4.03 & 3.97 & 3.91 & 3.85 \\
\hline $\mathrm{T}_{7}$ & 4.42 & 4.35 & 4.26 & 4.18 & 4.13 & 4.08 & 4.02 \\
\hline $\mathrm{T}_{8}$ & 4.36 & 4.29 & 4.22 & 4.15 & 4.10 & 4.05 & 3.99 \\
\hline $\mathrm{T}_{9}$ & 4.15 & 4.09 & 4.01 & 3.96 & 3.89 & 3.83 & 3.76 \\
\hline $\mathrm{CD}$ & 0.032 & 0.034 & 0.024 & 0.038 & 0.032 & 0.027 & 0.022 \\
\hline $\mathrm{SEm} \pm$ & 0.008 & 0.009 & 0.006 & 0.010 & 0.008 & 0.007 & 0.006 \\
\hline $\mathrm{F}$ test & $* *$ & $* *$ & $* *$ & $* *$ & $* *$ & $* *$ & $* *$ \\
\hline
\end{tabular}

** Significant at $1 \%$ level

NS - Non Significant

\section{Treatment details}

$\mathrm{T}_{1}$ : Pomegranate aril $(50 \%)+$ Pomegranate rind powder $(1 \%)+$ Jamun pulp $(20 \%)+$ Kokum $(5 \%)$

$\mathrm{T}_{2}$ : Pomegranate aril $(50 \%)+$ Pomegranate rind powder $(1 \%)+$ Jamun pulp $(20 \%)+$ Kokum $(10 \%)$

$\mathrm{T}_{3}$ : Pomegranate aril $(50 \%)+$ Pomegranate rind powder $(1 \%)+$ Jamun pulp $(30 \%)+$ Kokum $(5 \%)$

$\mathrm{T}_{4}$ : Pomegranate aril $(50 \%)+$ Pomegranate rind powder $(1 \%)+$ Jamun pulp $(30 \%)+$ Kokum $(10 \%)$

$\mathrm{T}_{5}$ : Pomegranate aril $(50 \%)+$ Pomegranate rind powder $(2 \%)+$ Jamun pulp $(20 \%)+$ Kokum $(5 \%)$

$\mathrm{T}_{6}$ : Pomegranate aril $(50 \%)+$ Pomegranate rind powder $(2 \%)+$ Jamun pulp $(20 \%)+$ Kokum $(10 \%)$

$\mathrm{T}_{7}$ : Pomegranate aril $(50 \%)+$ Pomegranate rind powder $(2 \%)+$ Jamun pulp $(30 \%)+$ Kokum $(5 \%)$

$\mathrm{T}_{8}$ : Pomegranate aril $(50 \%)+$ Pomegranate rind powder $(2 \%)+$ Jamun pulp $(30 \%)+$ Kokum $(10 \%)$

$\mathrm{T}_{9}$ : Pomegranate- $14{ }^{\circ} \mathrm{B}$ (Control) 
Table.3 Effect of different treatments on acidity (\%) content of nutraceutical enriched blended beverages during storage

\begin{tabular}{|c|c|c|c|c|c|c|c|}
\hline Treatments & 0 Days & 15 Days & 30 Days & 45 Days & 60 Days & 75 Days & 90 Days \\
\hline $\mathrm{T}_{1}$ & 0.38 & 0.45 & 0.52 & 0.58 & 0.63 & 0.69 & 0.75 \\
\hline $\mathrm{T}_{2}$ & 0.40 & 0.48 & 0.53 & 0.60 & 0.66 & 0.71 & 0.78 \\
\hline $\mathrm{T}_{3}$ & 0.32 & 0.39 & 0.45 & 0.53 & 0.59 & 0.64 & 0.70 \\
\hline $\mathrm{T}_{4}$ & 0.35 & 0.43 & 0.49 & 0.56 & 0.61 & 0.67 & 0.73 \\
\hline $\mathrm{T}_{5}$ & 0.43 & 0.50 & 0.57 & 0.67 & 0.73 & 0.81 & 0.89 \\
\hline $\mathrm{T}_{6}$ & 0.45 & 0.52 & 0.59 & 0.69 & 0.75 & 0.83 & 0.91 \\
\hline $\mathrm{T}_{7}$ & 0.41 & 0.49 & 0.56 & 0.64 & 0.70 & 0.77 & 0.83 \\
\hline $\mathrm{T}_{8}$ & 0.42 & 0.47 & 0.55 & 0.66 & 0.72 & 0.80 & 0.86 \\
\hline $\mathrm{T}_{9}$ & 0.56 & 0.62 & 0.71 & 0.80 & 0.91 & 0.97 & 1.03 \\
\hline $\mathrm{CD}$ & 0.021 & 0.024 & 0.028 & 0.021 & 0.022 & 0.024 & 0.024 \\
\hline SEm \pm & 0.005 & 0.006 & 0.007 & 0.006 & 0.006 & 0.006 & 0.006 \\
\hline $\mathrm{F}$ test & $* *$ & $* *$ & $* *$ & $* *$ & $* *$ & $* *$ & $* *$ \\
\hline
\end{tabular}

** Significant at $1 \%$ level

NS - Non Significant

\section{Treatment details}

$\mathrm{T}_{1}$ : Pomegranate aril (50\%) + Pomegranate rind powder (1\%) + Jamun pulp (20\%) + Kokum (5\%)

$\mathrm{T}_{2}$ : Pomegranate aril $(50 \%)+$ Pomegranate rind powder $(1 \%)+$ Jamun pulp $(20 \%)+$ Kokum (10\%)

$\mathrm{T}_{3}$ : Pomegranate aril $(50 \%)+$ Pomegranate rind powder $(1 \%)+$ Jamun pulp $(30 \%)+$ Kokum $(5 \%)$

$\mathrm{T}_{4}$ : Pomegranate aril $(50 \%)+$ Pomegranate rind powder (1\%) + Jamun pulp (30\%) + Kokum (10\%)

$\mathrm{T}_{5}$ : Pomegranate aril $(50 \%)+$ Pomegranate rind powder $(2 \%)+$ Jamun pulp $(20 \%)+$ Kokum $(5 \%)$

$\mathrm{T}_{6}$ : Pomegranate aril $(50 \%)+$ Pomegranate rind powder $(2 \%)+$ Jamun pulp (20\%) + Kokum (10\%)

$\mathrm{T}_{7}$ : Pomegranate aril $(50 \%)+$ Pomegranate rind powder $(2 \%)+$ Jamun pulp $(30 \%)+$ Kokum $(5 \%)$

$\mathrm{T}_{8}$ : Pomegranate aril $(50 \%)+$ Pomegranate rind powder $(2 \%)+$ Jamun pulp (30\%) + Kokum (10\%)

$\mathrm{T}_{9}$ : Pomegranate- $14 \stackrel{\circ}{\mathrm{B}}$ (Control)

Table.4 Effect of different treatments on ascorbic acid $\left(\mathrm{mg} 100 \mathrm{ml}^{-1}\right)$ content of nutraceutical enriched blended beverages during storage

\begin{tabular}{|c|c|c|c|c|c|c|c|}
\hline Treatments & 0 Days & 15 Days & 30 Days & 45 Days & 60 Days & 75 Days & 90 Days \\
\hline $\mathrm{T}_{1}$ & 57.60 & 51.20 & 46.40 & 40.00 & 35.20 & 30.40 & 27.20 \\
\hline $\mathrm{T}_{2}$ & 62.40 & 56.00 & 49.60 & 43.20 & 38.40 & 35.20 & 32.00 \\
\hline $\mathrm{T}_{3}$ & 59.20 & 52.80 & 48.00 & 41.60 & 36.80 & 32.00 & 28.80 \\
\hline $\mathrm{T}_{4}$ & 65.60 & 59.20 & 52.80 & 46.40 & 40.00 & 36.80 & 33.60 \\
\hline $\mathrm{T}_{5}$ & 46.40 & 40.00 & 33.60 & 28.80 & 25.60 & 22.40 & 19.20 \\
\hline $\mathrm{T}_{6}$ & 52.80 & 48.00 & 43.20 & 36.80 & 32.00 & 28.80 & 24.00 \\
\hline $\mathrm{T}_{7}$ & 49.60 & 43.20 & 36.80 & 30.40 & 27.20 & 24.00 & 20.80 \\
\hline $\mathrm{T}_{8}$ & 56.00 & 49.60 & 44.80 & 40.00 & 33.60 & 28.80 & 25.60 \\
\hline $\mathrm{T}_{9}$ & 40.00 & 33.60 & 27.20 & 22.40 & 17.60 & 14.40 & 11.20 \\
\hline $\mathrm{CD}$ & 16.600 & 15.281 & 13.054 & 15.350 & 14.648 & 14.720 & 14.791 \\
\hline $\mathrm{SEm} \pm$ & 4.316 & 3.973 & 3.394 & 3.991 & 3.809 & 3.827 & 3.846 \\
\hline $\mathrm{F}$ test & $* *$ & $* *$ & $* *$ & $* *$ & $* *$ & $* *$ & $* *$ \\
\hline
\end{tabular}

** Significant at $1 \%$ level NS - Non Significant

\section{Treatment details}

$\mathrm{T}_{1}$ : Pomegranate aril $(50 \%)+$ Pomegranate rind powder $(1 \%)+$ Jamun pulp $(20 \%)+$ Kokum $(5 \%)$

$\mathrm{T}_{2}$ : Pomegranate aril $(50 \%)+$ Pomegranate rind powder $(1 \%)+$ Jamun pulp $(20 \%)+$ Kokum $(10 \%)$

$\mathrm{T}_{3}$ : Pomegranate aril $(50 \%)+$ Pomegranate rind powder $(1 \%)+$ Jamun pulp $(30 \%)+$ Kokum $(5 \%)$

$\mathrm{T}_{4}$ : Pomegranate aril $(50 \%)+$ Pomegranate rind powder $(1 \%)+$ Jamun pulp $(30 \%)+$ Kokum $(10 \%)$

$\mathrm{T}_{5}$ : Pomegranate aril $(50 \%)+$ Pomegranate rind powder $(2 \%)+$ Jamun pulp $(20 \%)+$ Kokum $(5 \%)$

$\mathrm{T}_{6}$ : Pomegranate aril $(50 \%)+$ Pomegranate rind powder $(2 \%)+$ Jamun pulp $(20 \%)+$ Kokum $(10 \%)$

$\mathrm{T}_{7}$ : Pomegranate aril $(50 \%)+$ Pomegranate rind powder $(2 \%)+$ Jamun pulp $(30 \%)+$ Kokum $(5 \%)$

$\mathrm{T}_{8}$ : Pomegranate aril $(50 \%)+$ Pomegranate rind powder $(2 \%)+$ Jamun pulp $(30 \%)+$ Kokum $(10 \%)$

$\mathrm{T}_{9}$ : Pomegranate- $14 \mathrm{~B}$ (Control) 
Table.5 Effect of different treatments on alcohol (\%) content of nutraceutical enriched blended beverages during storage

\begin{tabular}{|c|c|c|c|c|c|c|c|}
\hline Treatments & 0 Days & 15 Days & 30 Days & 45 Days & 60 Days & 75 Days & 90 Days \\
\hline $\mathrm{T}_{1}$ & 3.41 & 3.54 & 3.68 & 3.80 & 3.88 & 3.96 & 4.04 \\
\hline $\mathrm{T}_{2}$ & 3.47 & 3.60 & 3.66 & 3.74 & 3.86 & 3.94 & 4.06 \\
\hline $\mathrm{T}_{3}$ & 3.16 & 3.28 & 3.40 & 3.51 & 3.60 & 3.68 & 3.80 \\
\hline $\mathrm{T}_{4}$ & 3.29 & 3.43 & 3.54 & 3.60 & 3.71 & 3.82 & 3.88 \\
\hline $\mathrm{T}_{5}$ & 3.62 & 3.71 & 3.78 & 3.86 & 3.98 & 4.06 & 4.12 \\
\hline $\mathrm{T}_{6}$ & 3.68 & 3.80 & 3.94 & 4.02 & 4.10 & 4.16 & 4.22 \\
\hline $\mathrm{T}_{7}$ & 3.51 & 3.62 & 3.74 & 3.82 & 3.94 & 4.00 & 4.08 \\
\hline $\mathrm{T}_{8}$ & 3.55 & 3.64 & 3.76 & 3.84 & 3.92 & 4.02 & 4.10 \\
\hline $\mathrm{T}_{9}$ & 3.76 & 3.84 & 3.92 & 4.00 & 4.10 & 4.18 & 4.26 \\
\hline $\mathrm{CD}$ & 0.029 & 0.021 & 0.031 & 0.021 & 0.031 & 0.027 & 0.028 \\
\hline $\mathrm{SEm} \pm$ & 0.007 & 0.006 & 0.008 & 0.005 & 0.008 & 0.007 & 0.007 \\
\hline $\mathrm{F}$ test & $* *$ & $* *$ & $* *$ & $* *$ & $* *$ & $* *$ & $* *$ \\
\hline
\end{tabular}

** Significant at $1 \%$ level NS - Non Significant

Treatment details

$\mathrm{T}_{1}$ : Pomegranate aril (50\%) + Pomegranate rind powder (1\%) + Jamun pulp (20\%) + Kokum (5\%)

$\mathrm{T}_{2}$ : Pomegranate aril $(50 \%)+$ Pomegranate rind powder $(1 \%)+$ Jamun pulp $(20 \%)+$ Kokum $(10 \%)$

$\mathrm{T}_{3}$ : Pomegranate aril $(50 \%)+$ Pomegranate rind powder $(1 \%)+$ Jamun pulp $(30 \%)+$ Kokum $(5 \%)$

$\mathrm{T}_{4}$ : Pomegranate aril $(50 \%)+$ Pomegranate rind powder $(1 \%)+$ Jamun pulp (30\%) + Kokum (10\%)

$\mathrm{T}_{5}$ : Pomegranate aril (50\%) + Pomegranate rind powder (2\%) + Jamun pulp (20\%) + Kokum (5\%)

$\mathrm{T}_{6}$ : Pomegranate aril (50\%) + Pomegranate rind powder (2\%) + Jamun pulp (20\%) + Kokum (10\%)

$\mathrm{T}_{7}$ : Pomegranate aril $(50 \%)+$ Pomegranate rind powder $(2 \%)+$ Jamun pulp $(30 \%)+$ Kokum $(5 \%)$

$\mathrm{T}_{8}$ : Pomegranate aril $(50 \%)+$ Pomegranate rind powder $(2 \%)+$ Jamun pulp (30\%) + Kokum (10\%)

$\mathrm{T}_{9}$ : Pomegranate- $14{ }^{\circ} \mathrm{B}$ (Control)

\section{Ascorbic acid (mg/100 ml)}

The decrease in the ascorbic acid content was observed in all the treatments of pomegranate blends during the storage period of 90 days. The higher ascorbic acid content was observed in $\mathrm{T}_{4}$ [Pomegranate aril $(50 \%)+$ Pomegranate rind powder $(1 \%)+$ Jamun pulp $(30 \%)+$ Kokum (10\%)], whereas, the lowest ascorbic acid content was recorded in $\mathrm{T}_{9}$ (Pomegranate $-14^{\circ} \mathrm{B}$ ). Decrease in ascorbic acid due to increase in the temperature and as the $\mathrm{pH}$ goes towards acidic it will depletes the ascorbic acid content (Fig. 2).

Similar results obtained by Kalra and Tandon (1984) were they reported decrease in TSS and ascorbic acid in storage of mango and guava juice. A study conducted by Brock et al., (1998) revealed that, ascorbic acid is very sensitive to thermal and pressure temperatures (Table 4).

\section{Alcohol (\%)}

Chikkasubbanna et al., (1990) reported that the alcohol percent of the grape wine increased due to a decrease in total soluble sugars due to the activity of yeast during fermentation, Adsule et al., (1992) estimated the alcohol content in pomegranate wine and reported that upon incubation alcohol content increased which was observed to be 6.6 per cent and Sapna et al., (2002) obtained an alcohol content of 6.57 to 6.75 per cent in Japanese wine, coriander wine had 7.05 to 
7.37 per cent in the thirds and after nine weeks of storage. The increase in alcohol content was due to the complete conversion of sugars to alcohol.

In the present investigation similar results were obtained which were in agreement with the results of previous workers. The increasing trend in the alcohol content was observed in storage period. The alcohol content of 4.26 per cent was found to be significantly highest in the treatment $\mathrm{T}_{9}$ (Pomegranate $-14{ }^{\circ} \mathrm{B}$ ). The lowest alcohol percentage of 3.80 was observed in the treatment $\mathrm{T}_{3}-$ [Pomegranate aril $(50 \%)+$ Pomegranate rind powder (1\%) + Jamun pulp $(20 \%)+$ Kokum $(5 \%)]$ (Table 5).

The following trends were observed during the storage of the prepared blended beverage, the alcohol per cent, the titratable acidity, organoleptic scores increased during storage period. Treatment $\mathrm{T}_{3}$ [Pomegranate aril $(50 \%)$ + Pomegranate rind powder $(1 \%)+$ Jamun pulp $(30 \%)+$ Kokum (5\%)] was found to be best when compared to all the other treatment and followed by Treatment $\mathrm{T}_{4}$ [Pomegranate aril $(50 \%)+$ Pomegranate rind powder $(1 \%)+$ Jamun pulp (30\%) + Kokum (10\%)] which was second best treatment as compared to other treatments. Whole pomegranate fruits can be utilised for fermentation and here the phenolic content may decrease and clarity of beverage can be obtained with better taste.

\section{References}

Adsule, R.N., Kadam, S.S., 1995, Preparation of wine from pomegranate juice, Poster Session 2. Phala Samskarana, 12: 2-17.

Adsule, R.N., Kotecha, P. M., Kadam, S.S., 1992, Preparation of wine from pomegranate. Beverage Food World, 19 (4): 113-114.

Bravo, A.F., Inigo, L.B., 1989, Biochemical and technological aspects of the biological ageing of Extremadura white wine. Alimentaria, 204: 43-46.

Brock, V.D., Ludikhuyze, L., Weemaes, C., Van, L.A., Hendrickx, M., 1998, Kinetics for isobaric isothermal degradation of L-Ascorbic acid. Journal of Agricultural and Food Chemistry 46(5): 2001-2006.

Caputi, A., Ueda, M., Brown, M.T., 1968, Spectrophotometric determination of ethanol in wine. The American Journal of Enology and Viticulture, 19:160-165.

Chikkasubbanna, V., Chadha, K.L., Ethiraj, S., 1990, Influence of maturity of Thomson Seedless grapes on the wine composition and quality. Indian Journal of Horticulture, 47: 12-17.

Kalra, S.K., D.K. Tandon, 1984. Guava nectar from sulphited pulp and their blend with mango nectar. Indian Food Packer, 38: 74-77.

Kulkarni, J.H., Singh, H., Chadha, K.L., 1980, Preliminary screening of mango variety for wine making. Journal of Food Science and Technology, 17: 218220.

Laminkanra, O., 1997, Changes in organic acid composition during fermentation and ageing of noble muscadine wine. Journal of Agricultural and Food Chemistry, 45(3): 935-937.

Olasupo, N.A., Obayori, O.S., 2003, Utilization of palm wine (Elaeis guinensis) for the improved production of Nigerian indigenous alcoholic drink Ogogoro Journal of Food Processing and Preservation, 27: 365372.

Patil, D.S., 1994, Studies on preparation of wine from commercially grown varieties of grape (Vitis vinifera L.). $M$. Sc. (Agri.) Thesis, Mahatma Phule Krishi Vidyapeeth, Rahuri, Dist. Ahmednagar, Maharashtra.

Ranganna, S., 1986, Handbook of analysis and quality control for fruits and 
vegetable products. $2^{\text {nd }}$ ed., Tata McGraw-Hill Publishing Co. Ltd. New Delhi. p: 126.

Sapna, V., Vasundhara, M., Annapurna, M.L., 2002. Fermented beverages from spices- a nutraceutical drink. Journal of Spices and Aromatic Crops. 11: 106111.

Taskar, N.V., 2007, Effect of different levels of diammonium hydrogen phosphate, sulphur dioxide and dilution on yield and quality of jamun (Syzigium cuminii Linn.) wine. M. Sc. (Agri.) Thesis, Dr. Balasaheb Sawant Konkan Krishi Vidyapeeth, Dapoli. Dist. Ratnagiri, Maharashtra.

Zeisel, S.H., 1999, Regulation of "Nutraceuticals". Science, 285: 185186.

\section{How to cite this article:}

Karan, M., K.N. Sreenivas, M. Chirag Reddy, G.S. Manjula and Mohamad Tayeeb Ulla, H. 2017. Pomegranate (Punica granatum L.) based Fermented Nutraceutical Product. Int.J.Curr.Microbiol.App.Sci. 6(12): 2054-2063. doi: https://doi.org/10.20546/ijcmas.2017.612.234 